Copyright (C) 2014 by Academic Publishing House Researcher

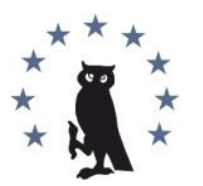

Published in the Russian Federation

European Researcher

Has been issued since 2010.

ISSN 2219-8229

E-ISSN 2224-0136

Vol. 81, No. 8-2, pp. 1551-1560, 2014

DOI: 10.13187/er.2014.81.1551

www.erjournal.ru

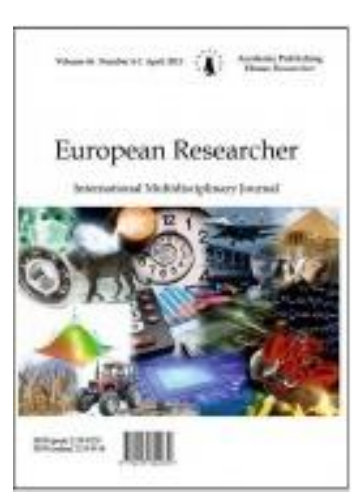

\title{
The Effects of Domestic Macroeconomic Determinants on Stock Returns: A Sector Level Analysis
}

\author{
Şerife Özlen
}

Ishik University, Iraq

Business and Management Department, Erbil

E-mail: serife.ozlen@ishik.edu.iq

\begin{abstract}
Investment analysis should be carefully performed in stock markets. Therefore, firms take necessary actions according to stock market behavior and macroeconomic variables. Therefore, the predictability of stock market determinants becomes important. This study aims to identify the effects of selected macroeconomic factors (interest rate, exchange rates, inflation-consumer price index, current account deficit, unemployment rates and sector indices) on stock returns of selected 48 companies in 11 different sectors of Istanbul Stock Exchange including electric, food, communication, paper, chemistry, metal-main, metal-product, stone, textile, commerce and transportation sectors. The study employs ARDL approach on the period between the second month of 2005 and the second month of 2012 including 85 monthly observations. According to the results, Sector Indices are found to be quite influential through the selected sectors. Exchanges rate is also significantly influential on almost all the sectors except Communication and Textile sectors. The impacts of Interest Rate, Inflation Rate, Current Account Deficit, and Unemployment Rate are various through the selected sectors. Moreover, the influence of Istanbul Stock Exchange Market on the stock returns of considered companies is significantly clear through the sectors except six companies (two companies from Paper sector, one company from Metal-Main sector, two companies from Stone sector and one company from Textile sector) out of 48 companies. Since it includes a wide range of companies and sectors, this study is expected to be useful for all policy makers and investment decisions.
\end{abstract}

Keywords: Macroeconomic factors; Sector level analyses; ARDL; ISE.

\section{Introduction}

Firms' stock market policies are becoming more and more important for the influences of macroeconomic variables. Fluctuations in macroeconomic variables affect business negatively by disturbing the tendency of the trade smoothness. Therefore, the predictability of stock market determinants becomes important. On the other hand, according to some studies, the predictability ratio has decreased for the last two decades (Lewellen, 2004; Cochrane, 2008).

The role of macroeconomic variables in asset pricing theories is accepted as important for financial analysts and policy makers. Therefore, many attempts are empirically performed in order to identify the link between macroeconomic variables and stock market volatility. Researchers (such as Errunza \& Hogan, 1998; Hamilton \& Lin, 1996; Schwert, 1989) observe that stock market 
volatility are linked to business cycle fluctuations. Investors, macroeconomists, politicians, and central bank managers want to better understand potential macroeconomic determinants of systematic financial-sector risk and business-cycle fluctuations in order to forecast stock market volatility.

Every country and stock exchange market have unique determinants specific to them. Therefore, for the same considered variables, they may have different responses. According to Fama (1990) and Binswanger (2000), Stock markets are mainly affected by the surrounding economy and useful to predict future economic conditions. Modern Portfolio Theory (MPT) argues that market risk is the key influencing factor of the equity prices. MPT asserts that an efficient set of portfolios can be constructed in order to offer the maximum possible expected return for a given level of risk (Markowitz, 1952). Sharpe (1964), Lintner (1965) and Black (1972) presented the capital asset pricing model as an extension of this theory by arguing that market risk cannot be diversified away, therefore it is the only risk in the pricing of a financial asset. However, Ross' (1976) arbitrage pricing theory (APT) becomes popular in developing multifactor models to explain stock returns. The APT is assumed to work only under perfectly competitive market.

One of the advantages of the APT, when compared to the CAPM, is enabling the market portfolio as a proxy which is not possible for the CAPM (Roll, 1977). When using the APT, this proxy which makes the APT easier to test empirically is not particularly important (Huberman, 1982). Researchers are aware that there is a need to add more than one factor before the APT is introduced. Brennan (1971) finds that minimum two factors should be used in an asset pricing model.

As a conclusion, a number of factors may have influence on the determination of the return on stocks, but they are not exactly known. In order to explain the stock returns two of the most important and common theories are capital asset pricing model (CAPM) and arbitrage pricing theory (APT). Instead of using a single market factor, the literature suggests the consideration of different variables to explain the stock return variations. Arbitrage Pricing Theory is a multi-factor asset pricing model which can be considered instead of the traditional equilibrium based model Capital Asset Pricing Model. According to Opfer and Bessler (2004), these models basically assume that the stock returns are generated by a limited number of economic variables or factors. The CAPM may not be able to fully explain the pricing of risky assets. Therefore, as a well-known alternative, instead of single risk based models the multifactor approach can be suggested either from an arbitrage pricing theory (APT) or from a multi-beta CAPM perspective in order to explain whether the market return is the only factor to define stock returns variations and what extramarket factors should be considered when investigating stock returns volatility. Furthermore, conditional means and variance in financial data can be applied in econometric analysis of financial markets.

This study aims to identify possible influences of some domestic macroeconomic variables (interest rate, exchange rates, inflation-consumer price index, current account deficit, unemployment rates and sector indices) on the selected 48 companies in 11 different sectors (electric, food, communication, paper, chemistry, metal-main, metal-product, stone, textile, commerce and transportation sectors) of Istanbul Stock Exchange (ISE) by employing an ARDL approach.

\section{Literature Review}

The role of financial information becomes important for the investment decisions. Because of the strong relation between economy and market, macroeconomic information may be very useful. External factors include governmental rules and regulations, inflation, investor behaviors, market conditions, money supply, competition, uncontrolled external circumstances, strikes, etc. The behavior of market participants can also be an important factor for stock prices. Macroeconomic variables are the factors which may have influence on corporate performance in products, services, and financial markets (currencies, interest rates, and consumer/ producer prices). Possible enterprise response to changes in external factors and their main effects should be measured by sensitivity coefficients (the change in a company's profit as a result of a change in each and every one of the most important macroeconomic variables) (Oxelheim, 2003). 
Enterprise vulnerability to changes in the macroeconomic environment can be expressed in terms of three sensitivity measurements including exchange rates, interest rates, and inflation rates (Oxelheim, 2003). Oxelheim (2003) suggests determination of the influencing variables for each category and a set of sensitivity coefficients within a multivariate framework for every company.

Oxelheim (2003) states that MUST (macroeconomic uncertainty strategy) analysis is one of the frameworks that enable a company to estimate sensitivity coefficients by finding (1) company specific macroeconomic variables, (2) performance outcomes of variance in these variables, and (3) a suitable strategy to control these variables. He reports that the first step in MUST analysis is the fundamental analysis of variables which have potential explanatory value. So, he recommends the selection of broad and complete relevant variables for a strong conclusion then the identification of most important macroeconomic variables from the potential variables by employing multivariate analyses and finally reducing the number of explanatory variables through stepwise regression with a backward elimination procedure until a satisfactorily large part of the variation is explained (Oxelheim, 2003).

\section{The interaction between macroeconomic variables and the stock returns}

According to Fama (1981), economic activity measures such as industrial production and inflation are influential in the analysis of stock market activity. Inflation is considered as an influencing factor of the movement of stock prices. The rise in inflation may cause tight monetary policies, which in turn increases the discount rate, therefore, the cost of borrowing and finally investment reduction in the stock market. Asprem (1989) assumes that inflation is positively related to stock return if stocks provide a hedge against inflation. On the other hand, Barrows and Naka (1994), Chen et al. (1986) and Chen et al. (2005) empirically identify the negative effect of inflation on the stock market. Normally, it is expected that inflation rate causes to restrictive monetary policies which in turn negatively influences stock prices.

Unexpected inflation can directly influence the stock market index negatively through unexpected changes in the price level. Malkiel (1982) observes a negative relationship between inflation rate and stock market prices because of two reasons: (1) inflation rate is directly related with interest rate and therefore negatively related to equity prices, (2) inflation rate may have a negative effect on profit margins for special groups of companies such as public utilities, leading to a decrease in their stock prices.

In their study, Chen et al. (1986) report industrial production, changes in the risk premium, twists in the yield curve, and inflation as the most significant variables to explain expected stock returns. There are several other factors to be included such as exchange rates, commodity prices, short term interest rates, and the difference between long term and short term interest rates.

Omran and Pointon (2001) and Boyd, Levine and Smith (2001) discover a negative correlation between inflation and market activity and liquidity, and between inflation rate and both stock market return and prices. Additionally, Apergis and Eleftheriou (2002) find that inflation has negative influence on stock prices in a high inflationary pressure economy in Greece. Du (2006) observes a positive correlation between stock market returns and inflation in the 1930s because of strong pro-cyclical monetary policy and strong negative relationship of stock returns and inflation between 1952 and 1974 because of shocks during this period.

Exchange rates are another variable of interest in the determination of stock value. It is observed from the literature that the effects of exchange rates are increasingly searched. While considering exchange rate fluctuations, the focus is on the conversion of assets, liabilities, and international cash flows (Oxelheim, 2003).

Oxelheim (2003) reports that shareholders and financial analysts do not prefer using corporate supply of relevant information related to macroeconomic fluctuations. Therefore, he searches and identifies the correlation between exchange rate and the other macroeconomic variables. Therefore, he suggests the consideration of this information while measuring and dealing with exchange rate exposure. 
There are two main considerations about interest rate fluctuations in accounting literature including the consideration of the debt (mainly foreign debt translation) and evaluation of financial instruments (Oxelheim, 2003).

By considering exchange rate channel of monetary policy transmission, local currency changes may drop the prices of export products and increase foreign demand and sales for exporting firms (Pan et al., 2007). Pan et al.'s (2007) 'exchange rate channel' is consistent with Dornbusch and Fisher's (1980) 'flow oriented' exchange rate model which asserts that exchange rate movements initially influence the international competitiveness and trade position, then the real output of the country, and finally the current and future cash flows of the company. As a result, both exchange rate channel and flow oriented models state that local currency negatively influences the firm value of exporting firms, and vice versa for the importing firms (Oxelheim, 2003).

The firms which are not directly involved in the export/import business are also influenced by exchange rate movements if their input prices, output prices, or product demand are related to exchange rate (Adler and Dumas, 1984). The literature about the relationship between stock markets and exchange rate gives mixed results. Aggarwal (1981) finds positive effects and Soenen and Hennigar (1988) identify negative influence of exchange rates on the stock market. Ibrahim (2000) employs three different exchange rate measures including real effective exchange rate, nominal effective exchange rate and RM/US\$ (home currency/dollar). However, he can not find long run relationship between stock market and exchange rates in a bi-variate setting in Malaysia. But after including money supply and reserves, he observes some evidence of the long run relationship among the four variables (stock market index, exchange rate, money supply and reserves). He furthermore identifies that money supply and reserves influence the stock market index in the short run.

According to Maysami and Koh (2000), when the effects of inflation and interest rate on stock price are considered, an increase in expected inflation rate may cause to tightening policies which can negatively influence stock prices.

Additionally, the Cash Flow Valuation Model suggests that inflation rate positively influences the nominal risk free rate and the discount rate. According to DeFina (1991), cash flows don't increase as inflation does and discount rate negatively affects stock prices.

Kim (2003) identifies that the S\&P 500 stock price is positively correlated with industrial production but negatively related with the real exchange rate, interest rate, and inflation. Ewing and Thompson (2007) observe the cyclical correlation among industrial production, consumer prices, unemployment, and stock prices by employing time series filtering methods.

Oxelheim (2003) considers the macroeconomic environment, by considering Oxelheim and Wihlborg (1987), as exchange rates, interest rates, inflation rates, and political risk premiums.

Mukherjee and Naka (1995) assert that both short-term and long-term interest rates may positively influence discount rates through their effect on nominal risk-free rates. Furthermore, according to them, restrictive policies by higher interest rates or discount rates can decrease cash flows value and therefore reduce the attractiveness of investment and minimizes the value of stock returns. By considering substitution effect, they continue that the rate of interest increases the opportunity cost of holding cash and causes to a substitution effect between stocks and other interest bearing securities like bonds. Treasury bill rates and interbank rates are commonly used interest rate proxies (Mukherjee and Naka, 1995; Maysami and Koh, 2000; Hooker, 2004).

Schwert (1989), Koutoulas and Kryzanowski (1996), and Maysami and Koh (2000) observe that macroeconomic variables can explain the developed U.S., Singapore, and Canada stock market movements. However, for the developing economies their influences present mixed results. 


\section{Research Methodology}

The Data

Since Istanbul stock exchange market is a relatively young market compared to the other developed markets, large amount of data cannot be achieved about the companies. This study selects 48 companies in 11 different sectors (electric, food, communication, paper, chemistry, metal-main, metal-product, stone, textile, commerce and transportation) of Istanbul Stock Exchange. The companies are selected according to FORTUNE 500 list for Turkey. The companies are selected by considering their data availability, profitability and performance in Istanbul Stock Exchange Market and they are considered as the representatives of their sectors. The data spans from the second month of 2005 to the second month of 2012 including 85 monthly observations.

This research prefers interbank interest rates as the proxy for interest rate. For exchange rates, dollar rates are considered. For inflation, consumer price index is chosen as the proxy. Moreover, Current account deficit represents the difference between import and export values. This study also uses unemployment rates and sector indices among domestic macroeconomic factors.

\section{Autoregressive Distributed Lag (ARDL)}

This research employs the autoregressive distributed lag (ARDL) approach in order to identify the relationships between stock returns and selected domestic macroeconomic variables. The ARDL method can provide the robust long-run results while working on small sample sizes and it can be applied if the primary variables are entirely I (1) or I (o) or mutually integrated.

The formula of the first ARDL analysis for identifying the relationship between the stock returns and domestic macroeconomic variables is given as follows:

$$
\begin{aligned}
\Delta \operatorname{Ln}(\mathrm{SR})_{\mathrm{t}}=\Psi_{0} & \\
& +\sum_{\mathrm{i}=1}^{\mathrm{n}} \Psi_{\mathrm{i}} \Delta \operatorname{Ln}(\mathrm{SR})_{\mathrm{t}-\mathrm{i}}+\sum_{\mathrm{i}=1}^{\mathrm{n}} \Psi_{\mathrm{i}} \Delta \operatorname{Ln}(\operatorname{InfR})_{\mathrm{t}-\mathrm{i}}+\sum_{\mathrm{i}=1}^{\mathrm{n}} \Psi_{\mathrm{i}} \Delta \operatorname{Ln}(\mathrm{ER})_{\mathrm{t}-\mathrm{i}}+\sum_{\mathrm{i}=1}^{\mathrm{n}} \Psi_{\mathrm{i}} \Delta \operatorname{Ln}(\operatorname{IntR})_{\mathrm{t}-\mathrm{i}} \\
& +\sum_{\mathrm{i}=1}^{\mathrm{n}} \Psi_{\mathrm{i}} \Delta \operatorname{Ln}(\mathrm{UR})_{\mathrm{t}-\mathrm{i}}+\sum_{\mathrm{i}=1}^{\mathrm{n}} \Psi_{\mathrm{i}} \Delta \operatorname{Ln}(\mathrm{CAD})_{\mathrm{t}-\mathrm{i}}+\sum_{\mathrm{i}=1} \Psi_{\mathrm{i}} \Delta \operatorname{Ln}(\mathrm{SI})_{\mathrm{t}-\mathrm{i}}+\alpha_{1} \Delta \operatorname{Ln}(\mathrm{SR})_{\mathrm{t}-1} \\
& +\alpha_{2} \Delta \operatorname{Ln}(\operatorname{InfR})_{\mathrm{t}-1}+\alpha_{3} \Delta \operatorname{Ln}(\mathrm{ER})_{\mathrm{t}-1}+\alpha_{3} \Delta \operatorname{Ln}(\operatorname{IntR})_{\mathrm{t}-1}+\alpha_{4} \Delta \operatorname{Ln}(\mathrm{UR})_{\mathrm{t}-1} \\
& +\alpha_{5} \Delta \operatorname{Ln}(\mathrm{CAD})_{\mathrm{t}-1}+\alpha_{6} \Delta \operatorname{Ln}(\mathrm{SI})_{\mathrm{t}-1}+\zeta_{\mathrm{t}-1}
\end{aligned}
$$

Where SR, InfR, ER, IntR, UR, CAD and SI denote stock returns, inflation rate, exchange rate, interest rate, unemployment rate, current account deficit and sector index respectively.

Before employing ARDL method, all macroeconomic data has been tested for unit root in order to identify whether the data are stationary through level and $1^{\text {st }}$ difference AkaikeInformation Criterion and it is observed that the data consist of both stationary and non-stationary information. According to the results, the data are found to be proper for ARDL approach. Therefore, ARDL is applied through four lags.

\section{Empirical Results}

In this section, the effects of domestic macroeconomic factors on the stock returns are presented with respect to their sectors. Below considerations are extracted from Table 1.

For Electric Sector, sector index is found to be significant for all companies. Then, except for one company exchange rate is observed to be significant. Unemployment rate, current account deficit and consumer price index are influential on some of the companies. But no significant effect of interest rate is observed.

Exchange rate is significant on almost all stock returns in Food Sector. Moreover, sector index, current account deficit and consumer price index are identified to have impact on stock returns. Unemployment rate and interest rate have influence on only one company in Food Sector. 
Consumer price index, interest rate and sector index are measured to be effective through Communication Sector. The other factors do not have significant effect on the sector.

According to the results, Paper Sector is influenced mainly by exchange rate and sector index. However unemployment rate and current account deficit have impact on some of the companies within the sector. The remaining factors do not have much influence on this sector.

For Chemistry Sector, the relationship between stock returns and sector index is found to be significant while the other factors are significant for few companies.

Exchange rate and sector index are the main influencing factors in Metal-Main Sector. After that current account deficit and interest are detected to have effect on some of the companies. On the other hand, unemployment rate and consumer price index seem not to have influence on the sector.

In Metal-Product Sector, wide influence of sector index is apparent. It is followed by consumer price index. The other factors are not very much influential on the company stocks.

Exchange rate is significantly associated with almost all companies through Stone Sector. Unemployment rate follows exchange rate as the second most influencing factor. But, the remaining factors have few relationships with the stock returns in Stone Sector.

About Textile Sector, it can be reported that sector index is clearly observed to be significant for all companies within the sector. The influence of interest rate is also significant on some of the companies. On the other hand, exchange rate has no significant relationship with the stock returns. The other factors do not have significant impact as sector index and interest rate.

In Commerce Sector, both exchange rate and sector index are found to be effective through the sector companies. All the other factors are also identified to have relationships with varying number of companies.

Finally, Transportation Sector is found to be effected by both interest rate and sector index. The remaining factors are effective on various stock returns through the sector.

TABLE 1: The Results for Domestic Macroeconomic Factors

\begin{tabular}{|c|c|c|c|c|c|c|c|}
\hline Sector & Company & $\begin{array}{c}\text { Unemployment } \\
\text { Rate }\end{array}$ & $\begin{array}{c}\text { Current } \\
\text { Account } \\
\text { Deficit }\end{array}$ & $\begin{array}{c}\text { Consumer } \\
\text { Price } \\
\text { Index } \\
\end{array}$ & $\begin{array}{c}\text { Interest } \\
\text { Rate }\end{array}$ & $\begin{array}{c}\text { Exchange } \\
\text { Rate }\end{array}$ & $\begin{array}{l}\text { Sector } \\
\text { Index }\end{array}$ \\
\hline \multirow{4}{*}{ Electric } & Akenr & Significant & & & & & Significant \\
\hline & Aksue & Significant & & & & Significant & Significant \\
\hline & Ayen & & Significant & Significant & & Significant & Significant \\
\hline & Zoren & & & & & Significant & Significant \\
\hline \multirow{5}{*}{ Food } & Aefes & & & & & & Significant \\
\hline & Banvt & & Significant & & & Significant & \\
\hline & Skple & & Significant & Significant & & Significant & Significant \\
\hline & Tatks & Significant & Significant & Significant & Significant & Significant & \\
\hline & Ulker & & & Significant & & Significant & Significant \\
\hline \multirow[t]{3}{*}{ Communication } & Tcell & & & Significant & Significant & & Significant \\
\hline & Hurgz & Significant & Significant & & Significant & Significant & Significant \\
\hline & Ipeke & Significant & & & & Significant & Significant \\
\hline \multirow[t]{4}{*}{ Paper } & Kartn & & & & & Significant & Significant \\
\hline & Kozaa & & Significant & & & Significant & Significant \\
\hline & Tire & Significant & Significant & Significant & & Significant & \\
\hline & Aksa & & Significant & Significant & Significant & Significant & Significant \\
\hline \multirow[t]{2}{*}{ Chemistry } & Aygaz & & & & & & Significant \\
\hline & Petkm & & & & & & Significant \\
\hline
\end{tabular}




\begin{tabular}{|c|c|c|c|c|c|c|c|}
\hline & $\begin{array}{l}\text { Trcas } \\
\text { Tuprs }\end{array}$ & Significant & Significant & Significant & Significant & Significant & $\begin{array}{l}\text { Significant } \\
\text { Significant }\end{array}$ \\
\hline \multirow{5}{*}{ Metal-Main } & Brsan & & & & & Significant & \\
\hline & Cemts & & Significant & & & Significant & Significant \\
\hline & Eregl & Significant & Significant & Significant & Significant & Significant & Significant \\
\hline & Izmde & & & & Significant & & Significant \\
\hline & Krdmd & & Significant & & & Significant & Significant \\
\hline \multirow{4}{*}{ Metal-Product } & Arclk & & Significant & & & Significant & Significant \\
\hline & Toaso & Significant & & Significant & & & Significant \\
\hline & Ttrak & Significant & & Significant & & & Significant \\
\hline & Vestl & & Significant & Significant & Significant & & Significant \\
\hline \multirow{6}{*}{ Stone } & Adana & & & & & Significant & \\
\hline & Afyon & Significant & & Significant & & Significant & \\
\hline & Anacm & & & Significant & & Significant & Significant \\
\hline & Golts & & Significant & & & & \\
\hline & Konya & Significant & & & Significant & Significant & \\
\hline & Trkem & Significant & Significant & & & Significant & \\
\hline \multirow{5}{*}{ Textile } & Altın & & & Significant & Significant & & Significant \\
\hline & Bossa & Significant & Significant & Significant & Significant & & Significant \\
\hline & Mndrs & & & & Significant & & Significant \\
\hline & Sktas & & & & & & Significant \\
\hline & Yunsa & & & & & & Significant \\
\hline \multirow{5}{*}{ Commerce } & Boynr & Significant & Significant & & Significant & Significant & Significant \\
\hline & Doas & Significant & Significant & Significant & Significant & Significant & Significant \\
\hline & Kipa & Significant & & Significant & Significant & Significant & Significant \\
\hline & Mgros & & Significant & & & Significant & Significant \\
\hline & Sanko & & Significant & & & Significant & Significant \\
\hline \multirow{3}{*}{ Transportation } & Clebi & & & & Significant & & Significant \\
\hline & Thyao & Significant & Significant & Significant & Significant & Significant & Significant \\
\hline & Ucak & Significant & & & Significant & & Significant \\
\hline
\end{tabular}

Note: The significance level is 0.05

As a summary, the influence of sector indexes is clear on the stock returns except Stone Sector. Beside this, the wide influence of exchange rate on the stock returns is also identified, while it has not influence on the companies in Communication and Textile Sectors. Moreover it can be stated that interest rate has influence on Communication and Transportation Sectors. The other factors have significant impacts on the stock returns with varying numbers.

\section{Conclusion}

This study analyzes the impact of macroeconomic variables on the stock returns of 48 companies from 11 sectors. Sector level analysis is good in that they can present implications for both investors and policy makers. The results for the evaluated sectors provide different information for the same factors. Therefore, it may be useful in order to get well diversified portfolios.

Sector Indices are found to be quite influential through the selected sectors. The companies are mainly influenced by their industry sector indices. 
Exchanges rate is also significantly influential on almost all the sectors except Communication and Textile sectors. The result for Textile Sector is found to be surprising. Because the companies in Textile Industry frequently use global currencies in their transactions, this relationship is expected to be significant.

The literature presents mixed results about the remaining macroeconomic factors. In line with the expectations, the impacts of Interest Rate, Inflation Rate, Current Account Deficit, and Unemployment Rate are various through the selected sectors.

The influence of Istanbul Stock Exchange Market on the stock returns of considered companies is significantly clear through the sectors except six companies (two companies from Paper sector, one company from Metal-Main sector, two companies from Stone sector and one company from Textile sector) out of 48 companies.

\section{References:}

Adler, M. and Dumas, B. (1984). Exposure to Currency Risk: Definition and Measurement. Financial Management, 13: 41-50.

Aggarwal, R. (1981). Exchange Rates and Stock Prices: A Study of the U.S. Capital Markets under Floating Exchange Rates. Akron Business Economic Review, 12, 7-12.

Apergis, N., \& Eleftheriou, S. (2002). Interest rates, inflation, and stock prices: the case of the Athens Stock Exchange. Journal of Policy Modeling, 24(3), 231-236.

Asprem, M. (1989). Stock Prices, Asset Portfolios and Macroeconomic Variables in Ten European Countries. Journal of Banking and Finance, 13, 589-612.

Barrows, C.W. and Naka, A. (1994). Use of Macroeconomic Variables to Evaluate Selected Hospitality Stock Returns in the U.S. International Journal of Hospitality Management, 13, 119128.

Binswanger, M. (2000). Stock market booms and real economic activity: is this time different? International Review of Economics and Finance, 9, 387-415.

Black, F. (1972). Capital Market Equilibrium with Restricted Borrowing. The Journal of Business, 45(3), 444-455.

Boyd, J. H., Levine, R. and Smith. (2001). The impact of inflation on financial sector performance. Journal of Monetary Economics, 47(2), 221-248.

Brennan, M. J. (1971). Capital Market Equilibrium with Divergent Borrowing and Lending Rates. The Journal of Financial and Quantitative Analysis, 6(5), 1197-1205.

Chen, M.H., Kim, W.G. and Kim, H.J. (2005). Macro and Non-Macro Explanatory Factors of Chinese Hotel Stock Returns. International Journal of Hospitality Management, 24, 243-258.

Chen, N., Roll, R., and Ross, S. A. (1986). Economic forces and the stock market. Journal of Business, 59 (3): 383-403

Cochrane, J. H. (2008). The Dog That Did Not Bark: A Defense of Return Predictability. Review of Financial Studies, 21:1533-75.

Defina, R.H. (1991). Does Inflation Depress the Stock Market?. Business Review, 3-12.

Du, D. (2006). Monetary policy, stock returns and inflation. Journal of Economics and Business, 58(1), 36-54.

Errunza, V. and Hogan, K. (1998). Macroeconomic determinants of European stock market volatility. European Financial Management, 4, 361-377. 
Ewing, B.T. and Thompson, M.A. (2007). Dynamic cyclical comovements of oil crices with industrial production, consumer prices, unemployment, and stock prices. Energy Policy, 35, 55355540 .

Fama, E. F. (1990). Stock returns, expected returns, and real activitiy. Journal of Finance 45, 1089-1108.

Fama, E. F. (1981). Stock returns, real activity, inflation, and money. American Economic Review, 71, 545-65.

Hamilton, J.D. and Lin, G. (1996). Hamilton and Lin, Stock market volatility and the business cycle. Journal of Applied Econometrics, 11, 573-593.

Hooker M. A. (2004). Macroeconomic Factors and Emerging Market Equity Returns: a Bayesian Model Selecting Approach. Emerging Markets Review, 5, 379-387.

Huberman, G. (1982). A simple approach to arbitrage pricing theory. Journal of Economic Theory, 28(1), 183-191.

Ibrahim, M.H. (2000). Co-integration and Granger Causality Tests of Stock Price and Exchange Rate Interactions in Malaysia. ASEAN Economic Bulletin, 17(1), 36-47.

Kim, K. H. (2003). Dollar exchange rate and stock price: evidence from multivariate cointegration and error correction model, Review of Financial Economics, 12 (3), 301-313.

Koutoulas, G. and Kryzanowski, L. (1996). Macro-factor Conditional Volatilities, TimeVarying Risk Premia and Stock Return Behavior. Financial Review, 31(1), 169-195.

Lewellen, J. (2004). Predicting returns with financial ratios. Journal of Financial Economics, 74 (2), 209-235.

Lintner, J. (1965). The valuation of risk assets and the selection of risky investments in stock portfolios and capital budgets. The Review of Economics and Statistics, 47, 13-39.

Malkiel, B. G. (1982). Risk and return: A new look, National Bureau of Economic Research Cambridge, Mass., USA.

Markowitz, H. (1952). Portfolio selection. Journal of Finance, 7(1): 77-91.

Maysami, R. and Koh, T.S. (2000). A Vector Error Correction Model of Singapore Stock Market. International Review of Economy and Finance, 9, 79-96.

Mukherjee, T.K. and Naka, A. (1995). Dynamic Relations between Macroeconomic Variables and the Japanese Stock Market: An application of a vector error-correction model. Journal of Financial Research, 18(2), 223-237.

Omran, M.and Pointon, J. (2001). Does the inflation rate affect the performance of the stock market? The case of Egypt. Emerging Markets Review, 2(3), 263-279.

Opfer, H. and Bessler, W. (2004). University of Giessen. FMA’s E-journal, June 2004.

Oxelheim, L. (2003). Macroeconomic Variables and Corporate Performance. Financial Analysts Journal, 59(4), 36-50.

Oxelheim, L., and C. Wihlborg. (1987). Macroeconomic Uncertainty-International Risks and Opportunities for the Corporation. New York: John Wiley \& Sons. 
Pan, M-S., Fok, R. C-W, Liu, Y. and Angela (2007). Dynamic Linkages between Exchange Rates and Stock Prices: Evidence from East Asian Markets. International Review of Economy and Finance, 16, 503-520.

Roll, R. (1977). A Critique of the Asset Pricing Theory's Tests Part I: On Past and Potential Testability of the Theory. Journal of Financial Economics, 4.

Ross, S. A. (1976). The Arbitrage Theory of Capital Asset Pricing. Journal of Economic Theory, 13(3), 341-360.

Schwert, G.W. (1989). Why does stock market volatility change over time? Journal of Finance, 44(5), 1115-1153.

Sharpe, W. F. (1964). Capital Asset Prices: A Theory of Market Equilibrium under Conditions of Risk. Journal of Finance, 19(3), 277-293.

Soenen, L. and Hennigar, E. (1988). An Analysis of Exchange Rates and Stock Prices: The US Experience (1980-1986). Akron Business and Economic Review, 19(4), 7-16. 